\title{
Correction: Integrative approach to sporadic Alzheimer's disease: deficiency of TYROBP in cerebral $A \beta$ amyloidosis mouse normalizes clinical phenotype and complement subnetwork molecular pathology without reducing $A \beta$ burden
}

\author{
Jean-Vianney Haure-Mirande ${ }^{1} \cdot$ Minghui Wang $^{2} \cdot$ Mickael Audrain $^{1} \cdot$ Tomas Fanutza $^{1} \cdot$ Soong Ho Kim ${ }^{1} \cdot$ \\ Szilvia Heja ${ }^{1} \cdot$ Ben Readhead $^{2} \cdot$ Joel T. Dudley ${ }^{2} \cdot$ Robert D. Blitzer $^{3} \cdot$ Eric E. Schadt $^{2,4} \cdot$ Bin Zhang $^{2} \cdot$ Sam Gandy ${ }^{1,5}$. \\ Michelle E. Ehrlich ${ }^{1,2,6}$
}

Published online: 21 November 2018

(c) The Author(s) 2018. This article is published with open access

Correction to: Molecular Psychiatry; https://doi.org/10. 1038/s41380-018-0255-6; published online 03 October 2018.

This article was originally published under standard licence, but has now been made available under a CC BY 4.0 license. The PDF and HTML versions of the paper have been modified accordingly.

Open Access This article is licensed under a Creative Commons Attribution 4.0 International License, which permits use, sharing, adaptation, distribution and reproduction in any medium or format, as long as you give appropriate credit to the original author(s) and the source, provide a link to the Creative Commons license, and indicate if changes were made. The images or other third party material in this article are included in the article's Creative Commons license, unless indicated otherwise in a credit line to the material. If material is not included in the article's Creative Commons license and your intended use is not permitted by statutory regulation or exceeds the permitted use, you will need to obtain permission directly from the copyright holder. To view a copy of this license, visit http://creativecommons. org/licenses/by/4.0/.
Bin Zhang

bin.zhang@mssm.edu

Sam Gandy

samuel.gandy@mssm.edu

$\square$ Michelle E. Ehrlich

michelle.ehrlich@mssm.edu

1 Department of Neurology, Icahn School of Medicine at Mount Sinai, New York, NY 10029, USA

2 Department of Genetics and Genomic Sciences and Icahn Institute of Genomic Sciences, Icahn School of Medicine at Mount Sinai, New York, NY 10029, USA

3 Departments of Pharmacological Sciences and Psychiatry, Icahn School of Medicine at Mount Sinai, New York, NY 10029, USA

4 Sema4, a Mount Sinai venture, Stamford, CT 06902, USA

5 Department of Psychiatry and Alzheimer's Disease Research Center, Icahn School of Medicine at Mount Sinai, New York, NY 10029, USA

6 Department of Pediatrics, Icahn School of Medicine at Mount Sinai, New York, NY 10029, USA 